Jurnal Pendidikan Islam Iqra' Vol. 11 Nomor 2 Tahun 2017

Fakultas Tarbiyah dan Ilmu Keguruan [FTIK]

IAIN Manado

\title{
SISTEM PENGELOLAAN KELAS DI INDONESIA DALAM KURIKULUM 2013
}

\author{
Lies Kryati, S. Pd, M. Ed. \\ Dosen Fakultas Tarbiyah dan Ilmu Keguruan (FTIK) IAIN Manado \\ e-mail:lkryati@gmail.com
}

\begin{abstract}
Abstrak
Sistem pengelolaan kelas di Indonesia merupakan kewajiban yang harus dilaksanakan dengan baik sesuai dengan kebijakan kurikulum 2013. Sehingga, proses belajar mengajar dapat berlangsung secara efektif dan efisien. Perbedaan tingkat kecerdasan, mental termasuk biologis peserta didik merupakan alasan mendasar.Kajian ini menunjukkan bahwa tujuan utama pengelolaan kelas adalah memberdayakan nalar, mental juga gerak peserta didik melalui pendekatan kekuasaan, ancaman, kebebasan, resep, pengajaran, perubahan tingkah laku, suasana emosi dan hubungan sosial, proses kelompok serta elektis atau pluralistik. Pendekatan ini mengikuti beberapa prinsip sekaligus keterampilan : hangat dan antusias, tantangan, bervariasi, keluwesan, pendekatan pada hal-hal yang positif, penanaman disiplin diri,sikap tanggap, membagi perhatian dan pemusatan perhatian kelompok. Kesimpulan dari kajian ini yaitu pengelolaan kelas berfokus kepada kegiatan pengaturan untuk kepentingan pengajaran. Pengelolaan kelas menyediakan fasilitas bagi berbagai kegiatan belajar peserta didik dalam lingkungan sosial, emosional, dan intelektual.
\end{abstract}

Kata Kunci : Sistem, Pengelolaan Kelas, Indonesia, Kurikulum 2013,

\section{Pendahuluan}

Kurikulum 2013 pertama kali diterapkan secara nasional pada awal TA 2014/2015 menjelang akhir masa jabatan Kabinet Pemerintahan Presiden Susilo Bambang Yudoyono. Kritik dan penolakan kemudian bermunculan dari berbagai daerah. Kementerian Pendidikan dan Kebudayaan Kabinet Kerja pemerintahan Presiden Joko Widodo kemudian melakukan evaluasi dan revisi terhadap beberapa bagian dari kurikulum yang baru tersebut. Kurikulum 2013 yang telah direvisi ini kemudian ditetapkan dan diterapkan kembali pada TA 2016/2017. Walaupun masih 
banyak kritik dan anjuran untuk revisi, kurikulum ini tetap dijalankan hingga sekarang. Di antara begitu banyak perbedaan antara Kurikulum 2013 dengan kurikulum-kurikulum sebelumnya, pengelolaan kelas adalah unsur yang paling banyak mendapat sorotan. Sorotan terhadap tata pengelolaan kelas tersebut muncul baik dari pemerhati pendidikan, pendidik, tenaga kependidikan, orang tua dan masyarakat luas dengan berbagai alasan.

Pengelolaan kelas adalah keterampilan guru untuk menciptakan dan memelihara kondisi belajar yang optimal dan memulihkannya bila terjadi gangguan dalam proses belajar mengajar. Keterampilan yang dimaksud antara lain adalah menghentikan tingkah laku peserta didik yang mengalihkan perhatian kelas, memberi ganjaran positif terhadap peserta didik yang menyelesaikan tugas tepat waktu, dan menerapkan norma kelompok yang produktif. Pengelolaan kelas berkaitan dengan usaha menciptakan dan mempertahankan kondisi sedemikian rupa sehingga proses pembelajaran berlangsung efektif dan efisien. Berbagai aspek pendidikan dan pengajaran seperti guru dengan keterampilan dan kemampuannya, peserta didik dengan segala latar belakang dan sifat-sifat individualnya, kurikulum dengan segala komponennya, dan materi dan bahan ajar serta pokok bahasannya bertemu, berproses dan berinteraksi di dalam kelas. Hasil yang diharapkan dari proses interaksi ini adalah tercapainya tujuan pembelajaran yang telah ditetapkan terlepas dari kurikulum apa yang digunakan.

Pengelolaan kelas yang baik menjadi penting karena peserta didik sebagai 'intake' dalam proses pembelajaran merupakan makhluk sosial yang berasal dari latar belakang yang berbeda-beda. Tiap-tiap peserta didik memiliki tingkat kecerdasan, kematangan psikologis dan biologis yang berbeda-beda sehingga menuntut kebijaksanaan guru dalam mengelola kelas. Dalam artikel ini, penulis mengangkat unsur pengaturan tempat duduk peserta didik yang sesuai dengan tututan Kurikulum 2013 dalam pengelolaan kelas. 
Jurnal Pendidikan Islam Iqra' Vol. 11 Nomor 2 Tahun 2017

Fakultas Tarbiyah dan Ilmu Keguruan [FTIK]

IAIN Manado

\section{Pembahasan}

\section{Pengertian dan Tujuan Pengelolaan Kelas}

Pengelolaan kelas secara umum dimaksudkan untuk menciptakan lingkungan belajar yang kondusif bagi peserta didik sehingga tujuan pembelajaran yang efektif dan efisien dapat dicapai. Untuk itu perlu dipahami pengertian pengelolaan kelas. Pengelolaan kelas terdiri dari dua kata yaitu pengelolaan dan kelas. Istilah pengelolaan berasal dari kata berbahasa Inggris "management", yang berarti ketatalaksanaan, tata pimpinan, pengelola. Menurut Arikunto (1990), pengertian umum manajemen atau pengelolaan dalam adalah pengadministrasian, pengaturan atau penataan suatu kegiatan. Sedangkan kelas yaitu sekelompok peserta didik pada waktu yang sama menerima pelajaran yang sama dari guru yang sama. Dari uraian tersebut dipahami bahwa pengelolaan kelas adalah suatu usaha sengaja dilakukan guna mencapai tujuan pengajaran. Karena itulah guru selalu berusaha mengelola kelas, walaupun terkadang kelelahan fisik maupun pikiran dirasakan.

Tujuan pengelolaan kelas pada dasarnya telah terkandung dalam tujuan pendidikan. Secara umum tujuan pengelolaan kelas adalah penyediaan fasilitas yang menunjang bermacam-macam kegiatan belajar peserta didik dalam lingkungan sosial, emosional, dan intelektual dalam kelas. Arikunto (1990) berpendapat bahwa tujuan pengelolaan kelas adalah agar setiap peserta didik di kelas dapat bekerja dengan tertib sehingga segera tercapai tujuan pengajaran secara efektif dan efisien. Menurutnya, sebagai indikator dari sebuah kelas yang tertib adalah apabila (1) Setiap anak terus bekerja, tidak macet, artinya tidak ada anak yang terhenti karena tidak tahu ada tugas yang harus dilakukan atau tidak dapat melakukan tugas yang diberikan kepadanya (2) Setiap anak terus melakukan pekerjaan tanpa membuang waktu, artinya setiap anak akan bekerja secepatnya supaya lekas menyelesaikan tugas yang diberikan kepadanya. 
Jurnal Pendidikan Islam Iqra' Vol. 11 Nomor 2 Tahun 2017

Fakultas Tarbiyah dan Ilmu Keguruan [FTIK]

IAIN Manado

\section{Berbagai Pendekatan dalam Pengelolaan Kelas}

Kurikulum 2013 yang sering disebut juga sebagai kurikulum yang berbasis pendidikan karakter menekankan pendidikan dan pembinaan karakter peserta didik. Guru dituntut untuk tidak hanya memperkaya aspek kognitif peserta didik, tetapi juga membangun asertif mereka. Keseimbangan antara kekayaan aspek kognitif dan asertif pada diri peserta didik diharapkan dapat membentuk generasi muda Indonesia yang cerdas, berkualitas dan berakhalak mulia. Untuk itu, diperlukan sebuah keharmonisan hubungan antara guru dengan peserta didik dan kerjasama antar peserta didik. Keharmonisan hubungan guru dengan peserta didik, tingginya kerja sama di antara peserta didik tersimpul dalam bentuk interaksi. Lahirnya interaksi yang optimal tentu saja bergantung dari pendekatan yang guru lakukan dalam rangka pengelolaan kelas. Berbagai pendekatan tersebut adalah seperti dalam uraian berikut:

\section{Pendekatan kekuasaan}

Pengelola kelas diartikan sebagai suatu proses untuk mengontrol tingkat laku anak didik. Peranan guru di sini adalah menciptakan dan mempartahankan situasi disiplin dalam kelas. Kedisiplinan adalah kekuatan yang menuntut kepada anak didik menaatinya. Di dalamnya ada kekuasaan dalam norma yang mengikat untuk ditaati anggota kelas. Melalui kekuasaan dalam bentuk norma itulah guru mendekatinya.

\section{Pendekatan ancaman}

Dari pendekatan ancaman atau intimidasi ini, pengelolaan kelas adalah juga sebagai suatu proses untuk mengontrol tingkah laku anak didik. Tetapi dalam mengontrol tingkat laku anak didik dilakukan dengan cara memberikan ancaman, misalnya melarang, mengejek, menyindir, dan memaksa.

\section{Pendekatan kebebasan}

Pengelolaan diartikan sebagai suatu cara untuk membantu peserta didik agar merasa bebas untuk mengerjakan sesuatu kapan saja dan dimana saja. Peran guru adalah mengusahakan semaksimal mungkn kebebasan anak didik. 
Jurnal Pendidikan Islam Iqra' Vol. 11 Nomor 2 Tahun 2017

Fakultas Tarbiyah dan Ilmu Keguruan [FTIK]

IAIN Manado

\section{Pendekatan resep}

Pendekatan resep (cook book) ini dilakukan dengan memberi satu daftar yang dapat menggambarkan apa yang harus dan apa yang tidak boleh dikerjakan oleh guru dalam mereaksi semua masalah atau situasi yang terjadi di kelas. Dalam daftar ini digambarkan tahap demi tahap apa yang harus dikerjakan oleh guru. Peran guru hanyalah mengikuti petunjuk seperti yang tertulis dalam resep.

\section{Pendekatan pengajaran}

Pendekatan ini didasarkan atas suatu anggapan bahwa dalam suatu perencanaan dan pelaksanakan akan mencegah munculnya masalah tingkah laku anak didik, dan memecahkan masalah itu bila tidak bisa dicegah. Pendekatan ini menganjurkan tingkah laku guru dalam mengajar untuk mencegah dan menghentikan tingkah laku anak didik yang kurang baik. Peran guru adalah merencanakan dan mengimplementasikan pelajaran yang baik.

6. Pendekatan perubahan tingkat laku

Sesuai dengan namanya, pengelolaan kelas diartikan sebagai suatu proses untuk mengubah tingkah laku anak didik. Peranan guru adalah mengembangkan tingkah laku yang baik, dan mencegah tingkah laku yang kurang baik. Untuk itu menurut pendekatan tingkah laku yang baik atau positif harus dirangsang dengan memberikan pujian atau hadiah yang menimbulkan perasanaan senang dan puas. Sebaliknya, tingkah laku yang kurang baik dan melaksanakan program kelas harus diberi sanksi atau hukuman yang akan menimbulkan perasaan tidak puas dan pada gilirannya tingkah laku tersebut akan dihindari.

7. Pendekatan suasana emosi dan hubungan sosial

Pendekatan pengelolaan kelas berdasarkan suasana perasaan dan suasana sosial di dalam kelas sebagai sekelompok individu cenderung pada pandangan psikologi kliniks dan konseling. Menurut pendekatan ini pengelolaan kelas merupakan suatu proses menciptakan iklim atau suasana emosional dan hubungan sosial yang positif. Suasana emosional dan hubungan sosial yang positif, artinya ada hubungan yang baik 
yang positif, artinya ada hubungan yang baik dan positif antara guru dengan peserta didik, atau antara anak didik dengan anak didik.

8. Pendekatan proses kelompok

Pengelolaan kelas diartikan sebagai suatu proses untuk menciptakan kelas sebagai suatu sistem sosial, di mana proses kelompok merupakan yang paling utama. Peranan guru adalah mengusahakan agar perkembangkan dan pelaksanaan proses kelompok yang efektif. Proses kelompok adalah usaha guru mengelompokkan anak didik ke dalam beberapa kelompok dengan berbagai pertimbangan individual sehingga tercipta kelas yang bergairah dalam belajar.

9. Pendekatan elektis atau pluralistik.

Pendekatan elektis ini menekankan pada potensialitas, kretivitas dan inisiatif wali/guru kelas dalam memilih beragai pendekatan tersebut berdasarkan situasi yang dihadapinya. Penggunaan pendekatan itu dalam suatu situasi mungkin dipergunakan salah satu dan dalam situasi lain mungkin harus mengombinasikan dan atau ketiga pendekatan tersebut. Pendekatan elektis di sebut juga pendekatan pluralistik, yaitu pengelolaan kelas yang berusaha menggunakan berbagai macam pendekatan yang memiliki potensi untuk dapat menciptakan dan mempertahankan suatu kondisi yang memungkinkan proses belajar mengajar berjalan efektif dan efisien.

\section{Prinsip-prinsip Pengelolaan Kelas}

1. Hangat dan antusias Hangat dan antusias diperlukan dalam proses belajar mengajar. Guru yang hangat dan akrab dengan anak didik selalu menunjukan antusias pada tugasnya atau pada aktivitasnya akan berhhasil dalam mengimplementasikan pengelolaan kelas.

2. Tantangan. Penggunaan kata-kata, tindakan, cara kerja atau bahan-bahan yang menantang akan meningkatkan gairah anak didik untuk belajar sehingga mengurangi kemungkinan munculnya tingkah laku yang menyimpang. 
Tambahan lagi, akan dapat menarik perhatian anak didik dan dapat mengendalikan gairah belajar mengajar.

3. Bervariasi. Penggunaan alat atau media, atau alat bantu, gaya mengajar guru, pola interaksi antara guru dan anak didik akan munculnya gangguan apa yang disebutkan diatas merupakan kunci untuk tercapainya pengelolaan kelas yang efektif dan menghindari kejenuhan.

4. Keluwesan. Keluwesan tingkah laku untuk mengubah strategi mengajarnya dan mencegah kemungkinan munculnya gangguan anak didik serta menciptakan iklim belajar mengajar yang efektif. Keluwesan pengajar dapat mencegah munculnya gangguan seperti keributan anak didik, tidak ada perhatian, tidak mengerjakan tugas, dan sebagainya.

5. Pendekatan pada hal-hal yang positif. Pada dasarnya dalam mengajar dan mendidik, guru harus menekankan pada hal-hal yang positif dan menghindari pemusatan perhatian anak didik pada hal-hal yang negatif. Penekanan pada hal yang positif, yaitu penekanan yang dilakukan guru terhadap tingkah laku anak didik yang positif daripada mengomeli tingkah laku yang negatif. Penekanan tersebut dapat dilakukan dengan pemberian penguatan yang dapat mengganggu jalannya proses belajar mengajar.

6. Penanaman disiplin diri. Tujuan akhir dari pengelolaan kelas adalah anak didik dapat mengembangkan disiplin diri sendiri. Karena itu, guru sebaliknya selalu mendorong anak didik untuk melaksanakan disiplin diri sendiri dan guru sendiri hendaknya menjadi teladan mengenai pengendalian diri dan pelaksanan tanggung jawab. Jadi, guru harus disiplin dalam segala hal bila ingin anak didiknya ikut berdisiplin dalam segala hal.

\section{Komponen-komponen Keterampilan Pengelolaan Kelas}

Keterampilan yang berhubungan dengan penciptaan dan pemeliharaan kondisi belajar yang optimal (bersifat preventif). Keterampilan ini berhubungan dengan kompetensi guru dalam mengembalikan inisiatif dan mengendalikan pelajaran serta aktivitas-aktivitas yang berkaitan dengan keterampilan sebagai berikut (a) Sikap 
Jurnal Pendidikan Islam Iqra' Vol. 11 Nomor 2 Tahun 2017

Fakultas Tarbiyah dan Ilmu Keguruan [FTIK]

IAIN Manado

tanggap (b) Membagi perhatian (c) Pemusatan perhatian kelompok. Keterampilan yang berhubungan dengan pengembangan kondisi belajar yang optimal Keterampilan ini berkaitan dengan tanggapan guru terhadap gangguan anak didik yang berkelanjutan dengan maksud agar guru dapat mengadakan tindakan remedial untuk mengembalikan kondisi belajar yang optimal. Apabila terdapat anak didik yang menimbulkan gangguan yang berulang-ulang walaupun guru telah menggunakan tingkah laku dan anggapan yang sesuai, guru dapat meminta bantuan kepala sekolah, konselor sekolah, atau orang tua anak didik, untuk membantu mengatasinya.

\section{Penataan Ruang Kelas}

Untuk menciptakan suasana belajar yang menggairahkan, perlu diperhatikan pengaturan/penataan ruang kelas/belajar. Penyusunan dan pengaturan ruang belajar hendaknya memungkinkan anak duduk berkelompok dan memudahkan guru bergerak secara leluasa untuk membantu peserta didik dalam belajar.

\section{Pengaturan Tempat Duduk}

Bentuk dan ukuran tempat duduk yang digunakan sekarang bermacam-macam, ada yang satu tempat duduk dapat diduduki oleh bebrapa orang, ada pula yang hanya dapat diduduki oleh seorang peserta didik. Sebaiknya tempat duduk peserta didik itu ukurannya jangan terlalu besar agar mudah diubah-ubah formasinya. Ada beberapa bentuk formasi tempat duduk yang dapat digunakan sesuai dengan kebutuhan. Apabila pengajaran itu akan ditempuh dengan cara berdiskusi, maka formasi tempat duduknya sebaiknya berbentuk melingkar. Jika pengajaran ditempuh dengan metode ceramah, maka tempat duduknya sebaiknya memanjang ke belakang.

Kurikulum 2013 menetapkan bahwa pengaturan tempat duduk peserta didik adalah secara berkelompok. Meja dan kursi di ruang kelas diatur sedemikian rupa sehingga peserta didik dapat duduk dalam kelompok yang terdiri dari empat hingga enam orang peserta didik. Pengaturan tempat duduk seperti ini memungkinkan peserta didik saling menghadap, berdiskusi dan berinteraksi dengan anggota kelompoknya selama jam pembelajaran berlangsung. Cara seperti ini mendukung anjuran Kurikulum 2013 tentang penerapan metode diskusi sebanyak mungkin 
selama proses belajar mengajar berlangsung. Guru tidak lagi selalu berada di depan kelas. Melainkan, guru didorong untuk aktif mengawasi dan membantu peserta didik dengan berjalan berkeliling kelas mendekati kelompok-kelompok yang membutuhkan penguatan, jawaban maupun penjelasan tambahan tentang materi pelajaran yang sedang dibahas.

Akan tetapi, tata cara pengaturan tempat duduk seperti ini belum dapat diterapkan secara menyeluruh di banyak sekolah. Salah satu alasan diantaranya adalah ukuran ruang kelas di sekolah-sekolah, ukuran meja kursi dan jumlah peserta didik yang besar dalam satu ruang kelas. Saat ini, di dalam satu ruang kelas yang berukuran 20 meter persegi terdapat 40 hingga 50 orang peserta didik. Dengan kondisi seperti ini, ruang kelas akan terlihat penuh sesak dan terasa tidak nyaman baik bagi peserta didik maupun guru. Dengan perbandingan luas ruang kelas dan jumlah peserta didik yang tidak ideal ini, tata cara pengaturan tempat duduk tradisional, yaitu semua peserta didik duduk berbanjar ke belakang, sehingga semua peserta didik menghadap ke depan kelas. Hal inilah yang kemudian membuat Dewan Guru dan Kepala Sekolah memutuskan untuk tidak menerapkan pengaturan tempat duduk yang dianjurkan oleh kurikulum 2013.

\section{Pengaturan Alat-Alat Pengajaran}

Di antara alat-alat pengajaran di kelas yang harus diatur adalah sebagai berikut (a) Perpustakaan kelas (b) Alat-alat peraga media pembelajaran (c) Papan tulis, kapur tulis, dan lain-lain (d) Papan presensi peserta didik (e) Penata keindahan dan kebersihan kelas (f) Pengaturan peserta didik. Di depan telah di uraikan mengenai pengaturan tempat duduk peserta didik dengan formasi yang bervariasi sesuai dengan kebutuhan dalam rangka mencapai tujuan pembelajaran. Masalahan pengaturan tempat duduk itu sebenarnya akan berhubungan dengan permasalahan peserta didik sebagai individu dengan perbedaan pada aspek biologis, intelektual, dan psikologis.

Abu Ahmadi dan Widodo Supriyono (1991) melihat peserta didik sebagai individu dengan segala perbedaan dan persamaannya. Berbagai persamaan dan perbedaan kepribadian peserta didik, berguna dalam membantu usaha pengaturan 
peserta didik di kelas. Terutama berhubungan dengan masalah bagaimana pola pengelompokan peserta didik guna menciptakan lingkungan belajar yang aktif dan kreatif, sehingga kegiatan belajar yang penuh kesenangan dan bergairah dapat bertahan dalam waktu yang relative lama.Kegiatan belajar mengajar dengan pendekatan kelompok menghendaki peninjauan pada aspek individual peserta didik. Penempatan peserta didik memerlukan pertimbangan pada aspek postur tubuh peserta didik, di mana menempatkan peserta didik yang mempunyai tubuh tinggi atau rendah, di mana menempatkan peserta didik yang memiliki kelainan penglihatan atau pendengaran, jenis kelaminan peserta didik perlu juga dijadikan pertimbangan dalam pengelompkan peserta didik. Peserta didik yang cerdas, yang bodoh, yang pendiam, yang lincah, dan suka berbicara, suka membuat keributan, yang suka mengganggu temannya, dan sebagainya. Sebaiknya dipisah agar kelompok tidak dominasi oleh satu kelompok tertentu, agar persaingan dalam belajar berjalan seimbang.

\section{Pengelolaan Kelas yang Efektif}

Bila kelas diberikan batasan sebagai sekelompok orang yang belajar bersama, yang mendapatkan pengajaran dari guru, maka di dalamnya terdapat orang-orang yang melakukan kegiatan belajar dengan karakteristik meraka masing-masing yang berbeda dari yang satu dengan yang lainnya.Perbedaan ini perlu guru pahami agar mudah dalam melakukan pengelolaan kelas secara efektif. Menurut Made Pidarta untuk mengelola kelas secara efektif perlu diperhatikan hal-hal sebagai berikut:

1. Kelas adalah kelompok kerja yang diorganisasi untuk tujuan tertentu,yang dilengkapi oleh tugas-tugas dan diarahkan oleh guru.

2. Dalam situasi kelas, guru bukan tutor untuk satu pada waktu tertentu, tetapi bagi semua anak atau kelompok.

3. Kelompok mempunyai perilaku sendiri yang berbeda dengan perilakuperilaku masing-masing individu dalam kelompok itu. Kelompok mempengaruhi individu-individu dalam hal bagaimana mereka memandang dirinya masing-masing dan bagaimana belajar. 
4. Kelompok kelas menyisipkan pengaruhnya kepada anggota-anggota. Pengaruh yang jelek dapat dibatasi oleh usaha guru dalam membimbing mereka di kelas di kala belajar.

5. Praktik guru waktu belajar cendrung terpusat pada hubungan guru dan peserta didik. Makin meningkat keterampilan guru mengelola secara kelompok, makin puas anggota-anggota di dalam kelas.

6. Struktur kelompok, pola komunikasi, dan kesatuan kelompok ditentukan oleh cara mengelola, baik untuk mereka yang tertarik pada sekolah maupun bagi mereka yang apatis, masa bodoh atau bermusuhan.Ditambahkannya lagi, bahwa organisasi kelas tidak hanya berfungsi sebagai dasar terciptanya interaksi guru dan peserta didik, tetapi juga menambah terciptannya efektivitas, yaitu interaksi yang bersifat kelompok.

Dari hasil riset telah disimpulkan beberapa variable masalah yang diperhatikan untuk membuat iklim kelas yang sehat dan efektif, sebagai berikut. Bila situasi kelas memungkinkan anak-anak belajar secara maksimal, fungsi kelompok harus diminimalkan. Manajemen kelas harus memberikan fasilitas untuk mengembangkan kesatuan dan kerja sama. Anggota-anggota kelompok harus diberi kesempatan berpartisipasi dalam mengambil keputusan yang member efek kepada hubungan dan kondisi belajar/kerja. Anggota-anggota kelompok harus dibimbing dalam menyelesaikan kebimbangan, ketegangan, dan perasan tertekan. Perlu diciptakan persahabatan dan kepercayaan yang kuat antar peserta didik. Keharmonisan hubungan guru dan peserta didik mempunyai efek terhadap pengelolaan kelas. Guru yang apatis terhadap peserta didik membuat peserta didik menjauhinya. Peserta didik lebih banyak menolak kehadiran guru. Rasa benci yang tertanam di dalam diri peserta didik menyebabkan bahan pelajaran sukar diterima dengan baik.

Kecenderungan sikap peserta didik yang negatif lebih dominan. Sifat kemunafikan ini menciptakan jurang pemisahan antara guru dan peserta didik. Lain halnya dengan guru yang selalu memperhatikan peserta didik, selalu terbuka, selalu 
tanggap keluhan peserta didik, selalu mau mendengarkan saran dan kritikan dari peserta didik, dan sebagainya, adalah guru yang disenangi oleh peserta didik. Peserta didik rindu akan kehadirannya, peserta didik senang mendengarkan nasihatnya, peserta didik merasa aman di sisinya, peserta didik senang belajar bersamanya, dan peserta didik merasa bahwa dirinya adalah bagian dari diri guru tersebut.Itulah figur seorang guru yang baik. Figur guru yang demikian biasanya akan kurang menemui kesulitan dalam mengelola kelas. Gordon (1990) mengatakan bahwa hubungan guru dan peserta didik dikatakan baik apabila hubungan itu memiliki sifat-sifat sebagai berikut:

1. Keterbukaan, sehingga baik guru maupun peserta didik saling bersikap jujur dan terbuka diri satu sama lain.

2. Tanggapan bilamana seseorang tahu bahwa dia dinilai oleh orang lain.

3. Saling Ketergantungan, antara satu dengan yang lain.

4. Kebebasan, yang memperbolehkan setiap orang tumbuh dan mengembangkan keunikannya, kreativitasnya, dan kepribadiannya.

5. Saling memenuhi kebutuhan, sehingga tidak ada kebutuhan satu orang pun yang tidak terpenuhi.

Bila begitu pengelolaan kelas yang efektif, maka itu berarti tugas yang berat bagi guru adalah berusaha menghilangkan atau memperkecil permasalahan-permasalahan yang terkait dengan semua problem pengelolaan kelas, seperti kurangnya kesatuan, tidak ada standar perilaku dalam bekerja kelompok, reaksi negatif terhadap anggota kelompok, moral rendah, kelas mentolerasi kekeliruan-kekeliruan temannya, dan sebagainya.

\section{Penutup}

Pengelolaan kelas merupakan kegiatan pengaturan kelas untuk kepentingan pengajaran. Pengelolaan kelas bertujuan menyediakan fasilitas bagi bermacammacam kegiatan belajar peserta didik dalam lingkungan sosial, emosional, dan intelektual dalam kelas. Walaupun tata cara pengaturan tempat duduk peserta didik 
yang dianjurkan oleh Kurikulum 2013 belum dapat dilaksanakan oleh sebahagian besar sekolah, berikut adalah hal-hal yang perlu diperhatikan dalam mengelola kelas. Kelas adalah kelompok kerja yang diorganisasi untuk tujuan tertentu,yang dilengkapi oleh tugas-tugas dan diarahkan oleh guru. Dalam situasi kelas, guru bukan tutor untuk satu pada waktu tertentu, tetapi bagi semua anak atau kelompok. Kelompok mempunyai perilaku sendiri yang berbeda dengan perilaku-perilaku masing-masing individu dalam kelompok itu. Kelompok kelas menyisipkan pengaruhnya kepada anggota-anggota. Praktik guru waktu belajar cendrung terpusat pada hubungan guru dan peserta didik. Struktur kelompok, pola komunikasi, dan kesatuan kelompok ditentukan oleh cara mengelola, baik untuk mereka yang tertarik pada sekolah maupun bagi mereka yang apatis, masa bodoh atau bermusuhan.

\section{Daftar Pustaka}

Ahmadi, Abu_\&_Widodo, Supriyono _ 1991. Psikologi Belajar 2 Rineka Cipta, Jakarta.

Arikunto, Suharsimi. 1988. Pengelolaan Kelas dan Peserta didik Sebuah Pendekatan Evaluatif, Jakarta.

Gordon, Thomas. 1990. Guru yang Efektif : Cara untuk Mengatasi Kesulitan dalam Kelas, Disadur oleh Drs. Mudjito, M.A. Rajawali Press. Jakarta. 